\title{
Comprehensive reflection and prospective of law education in China
}

\author{
Hong Wang ${ }^{1, a}$ \\ ${ }^{1}$ Liaoning Police College, Dalian, Liaoning Province, China \\ a675087603@qq.com
}

Keywords: China law, Legal education, Reflection, Prospective

\begin{abstract}
Law education from the restoration and reconstruction to the continuous reform, prosperity and development formed with a large, relatively reasonable structure, gradually improve the quality of education of the education system of law, the Chinese model of legal education has been initially formed. Also face challenges at the same time, the need for China to rethink the positioning of legal education, further adjusting and perfecting China's legal education mode of education, education institutions, education level, education mode, continuously improve the quality of education. The Chinese model for the future of law education will gradually mature and perfect.
\end{abstract}

\section{Introduction}

China's law education after nearly 60 years of development has been at a new crossroads, "on the one hand, the education of law shows the good situation of unprecedented prosperity, prosperity; on the other hand, it is hidden behind the deep contradiction [1]. These contradictions, some have been fully exposed, some contradictions are still being formed”. In my opinion, the education of law in this intersection has been around for several years, now it's time to choose [1]. All law, including legal education researchers, education administrators, educators, educated, have obligation to carefully study the scientific law of education of law, reflections on China's law education present situation and existing problems, and combining the reality of China, trying to choose a bright way for legal education.

\section{The plight of the Chinese legal education}

Since the founding of new China 60 years, the achievements of China's law education should be fully recognized.However, the challenge is very much also.There are both the disadvantages of left over by history, and the issues of development, there are also emerging contradictions; There are both the lack of macroscopic social regulation, and management model of medium hole, also has the defects of the system of the micro operation.Mainly concentrated in the following aspects:

The teaching material content heavy theory, light practice. In the process of teaching, teaching material is an important medium. Professional teaching materials of law as an important carrier of legal professional teaching content that plays an important role in the teaching process, teaching material writing mode and contents of quality directly affects the talent training quality [2]. However, in the "heavy theory, light practice" traditional idea, under the leading of the current mode of legal science specialized textbook determines $90 \%$ or more of the teaching material content belong to the legal theory is introduced, the basic no case knowledge and practice. The theory from practical teaching mode in theory of law and legal practice, so that the students are difficult to comprehend the realistic significance of the knowledge of law and the essence of legal theory, the lack of the legal theory combined with a specific case; Moreover, this kind of boring textbook learning, inspire students' interest in learning. Although now a lot of teachers in classroom teaching process, will arrange discussion or moot court trial in some cases, to make up the defects of the teaching material, enhancing students' perceptual knowledge in legal theory. However, classroom teaching, after all, is a dynamic process from not repetitive; And case discussion or moot court trial as a classroom teaching skills, they are used or not in the teachers, so it is difficult to immobilized, standardization, and the steps. 
The practice of the legal science specialized curriculum. Curriculum is the outline of the syllabus, which is the core content of the talent training scheme [2].Curriculum is scientific or not directly affect the implementation of the training process and the realization of training objectives.General professional courses in major of law is composed of the compulsory courses and elective courses: a, compulsory course for the ministry of education regulations 14 core courses, including jurisprudence, constitution, the Chinese legal, criminal law, civil law, commercial law, intellectual property law, economic law, administrative law and administrative procedure law, civil procedure law, criminal procedure law, international law, private international law, international economic law.b, courses in different colleges and universities are different, but basically the same, mainly including the Chinese and foreign, foreign legal ideology, legal, environmental law, the state compensation law, criminal investigation science, criminology, prison law, lawyers and notary system, contract law, commercial law, competition law, company law, tax law, finance law, tort law, labor and social security act, marriage and family law, law, etc.

Old classroom teaching mode. Classroom teaching is the main form of legal education, about more than three-quarters of the teaching time [3].Therefore, the choice of the ways of classroom teaching effect of classroom teaching and the cultivation of students' ability is very important.Look from the current practice of teaching, most teachers still use the traditional force-feeding teaching way, to teach legal concept, legal system, theoretical perspectives. This teaching method can quickly and comprehensive knowledge to students, but in the teaching process teachers just a information output machine, students also is just a simple information of the receiver, the lack of interaction between teachers and students, dull classroom teaching atmosphere.This is not conducive to the cultivation of students innovative thinking and practical ability.

Teaching practice become a mere formality. Although the lack of practice in the legal science specialized curriculum courses, but no practice is not to say that the whole teaching process.At present, the most professional law stipulate the practice in the teaching plan, generally about $10 \%$ of the total class hours.However, problems in the practice teaching link these become a mere formality [3].In the case of graduation practice, graduation practice of legal professional general Settings in the fourth year, internship units or link by the school, or by the students themselves, with the method of dispersing internship, more commonly known as "sheep".In the process of graduation practice, teachers usually only responsible for keep in touch with the student, and did not establish direct contact with the internship units.Because of graduation practice locations all over the country, is relatively fragmented, and the nature of the internship units are different, so the teacher can't to student's practice to implement supervision and guidance of the distance, is also difficult to comprehensive study of the students' practice content and practice effect [3].Even so, the current form of graduation practice has also been the behavior of the students are busy looking for a job in one basic erosion.Under the huge pressure of employment, the university students of grade four graduation practice it is difficult to confidently, often use the internship time around looking for jobs, or preparing for graduate students, civil service exam.Even some students carried out graduation practice, the practice content may also have nothing to do with legal professional ability of exercise.

Insufficient management relative lag, regulation and control mechanism. China's law education, although after the prosperous development of more than 60 years, but, so far no law education to develop a unified access system, both the lack of specification requirements, no institutionalized exit mechanism, more the lack of perfect supervision and management mechanism [4].Due to the lack of a unified national about legal departments approved conditions and qualifications censorship rules, any university can basically decide to set up the law department or legal professional, the resulting legal education inevitably appear the situation of out of control.To this, although the ministry of education in 1997 to set up the law subject teaching steering committee, played a role, however, because the law subject teaching steering committee is by the ministry of education management and some scholars of institutions of higher learning and scientific research institutions, distribution, in addition to the limited focus on meeting to discuss each year, most of the members are busy in their own almost have nothing to do with law subject management affairs, neither the education work of running a long-term mechanism of law, no hard, difficult to the 
problems of law education to pay system, and targeted to think and plan for a long time.Law education after 60 years, especially after thirty years with the rapid development of restoration and reconstruction, needs to establish a set of standard scientific settlement control mechanism.

Excessive marketization of education of law, the economic interests of the driver. Before the reform and opening up 30 years, due to reasons known to all, China's law education political weight.1978 years later, the situation of reform and opening up, has brought the rare opportunity to the development of law education [4].Countries need to have both in a relatively short period of time to cultivate a large number of legal talents enrich the judges, prosecutors, lawyers and judicial administration team, and need a large number of engaged in legislative, administrative law enforcement and management of social and national legal professionals. This situation has brought law education opportunity, making various kinds of law education to flourish, at the same time, the marketization of education has become an irreversible trend.

\section{China's law education outlook in the future}

Focuses on legal education with general education is given priority to, the comments of law education, legal education from the knowledge as the center gradually evolved into professional oriented.The next 30 years the development direction of China's law education is mainly manifested in the following aspects:.

To increase practice and legal comprehensive ability training course. The lack of practice courses in major of law lead to students lack even the most basic practice ability, so must to reform the existing curriculum, increase practice courses [5].The author thinks that, first of all, professional theory and practice of law to the class of the class ratio adjustment is $6: 4$, and gradually transition to 5:5;Second, in order to to match the theory courses, should also be separately set "civil case analysis" "criminal case analysis" "administrative case analysis" and other practical courses;Third, to strengthen the cultivation of students' ability to handle the case, "legal clinic" lawyer "practice" should be taught "arbitration" and other practical courses;Fourth, in order to meet the needs of enterprises for legal professionals, "legal practice" and other practices should be taught.

To basic understanding form. Basic understanding is a basic concept in the cognitive level of the specific expression, is expected to gradually formed a basic understanding of students in learning activities, is the core of specific facts and deep understanding of the essence of the concept [5]. The determination of basic understanding of the concept of "construction" of teaching operable. The determination of basic understanding requires teachers to accurately grasp the students' cognitive basis and thinking level.

Reform in the teaching material of writing mode. Law teaching professional shall follow the principle of paying equal attention to both theory and practice.The author thinks that, representative, inspirational case should be a large number of materials into law, in order to deepen students' understanding of the theory and enhance students' ability to analyze and solve problems, make the teaching more targeted and operability and effectiveness [5].Especially strong theoretical teaching materials, such as general jurisprudence, civil law and legal thought, more should be combined with a large number of cases to explain to the theory and analysis, makes the student to the abstract theory have a perceptual knowledge.At present, the individual legal textbooks have been trying to put a large number of cases into teaching materials, but mostly in theory content of each chapter, after the case listed in the assignments section for informative, generally do not do the analysis.This although compared with the traditional jurisprudence teaching mode has improved, but the case is not in the content of the theory of thrust, and the lack of proper analysis, so the effect is not ideal.

Readjust China's law education function. When the relationship between legal education and legal profession has been, legal professional ethics and skills education is widely appeal, the relationship between law and justice has been questioned, when the national judicial examination in $200780 \%$ of the candidate is unable to correctly interpret the connotation of the idea of socialist rule of law, people began to realize that the next Chinese jurisprudence education new pace is about to take in more than 60 years, urgent need for the future of China's law education to be a clear positioning. 
At the same time, China's law education for more than six decades of practice development also tells us, along with the deepening of the country under the rule of law process, especially the establishment of the national uniform judicial examination system, the Chinese traditional law education positioning of the historical mission has been completed [6].At the same time, it is necessary to readjust the Chinese jurisprudence education from general education to general education, professional education and elite education, combining the function orientation of transformation, the training goal of legal education from a single legal knowledge training into applied talents of law, law research personnel and social management personnel jointly develop.In the construction of the country under the rule of law in the future, which requires the legal profession must be took to the track of professionalization and specialization, law education is shouldering the legal professional departments and the whole society to cultivate high-quality talents in the field of legal history mission.

With hierarchical set law department of evaluation. Law department setting is the important factor affecting the development of law education.In view of the present Chinese law schools set size, though large, but in the structure of talent training is a disequilibrium situation.Mainly engaged in legal research and academic law department of legal education theory type legal talent[6]. Mainly focus on the career in the legal practice type law department specialized legal talent oriented;Feature class law department mainly lay particular stress on cultivating legal talent with professional characteristics, such as finance, agriculture, forestry and class, language class law departments of colleges and universities.And academic faculty of law, and the practice, characteristics of law department, all can be divided into elite and ordinary, elite law schools can cultivate academic, practical and characteristic multi-level legal talent, while ordinary law department can only engage in the practice and characteristics of legal education.

A law degree education level optimization adjustment. At present, China's higher education of law system level is much, but, all levels of education generally there are some questions of law, and the entire education system has not been effectively integrate resources of law, legal education of each level, each module individually, the overall quality of the education of law is not high.For a long time, not standing on the height of China's law education system, overall knowledge and solving legal science specialized subject and undergraduate course, master of law, law master and doctor of law education reform and development, vision is too narrow, then caused the law education at all levels within and between the various levels of many contradictions, which also makes the overall strength of legal education is weakening.Optimization adjustment law degree education level is the necessity of the future development of Chinese law education, and integration of law education resources, the important way to improve the quality of education of law. The fundamental goal of legal education is talent of education law, according to the future Chinese jurisprudence of law application talents education, legal research talents and social management talent orientation, law application talents demand for a law degree is relatively low.

Law education and judicial examination and the legal profession benign interaction. Legal education and legal profession are "source" and "living water" complement each other, the dialectical relationship of symbiosis [7].Face of China's legal education and legal profession is repeatedly criticized the disconnect between the status quo, the future of law education should be with the national judicial examination and the benign interaction between and among the legal profession.In legal education of the future, first of all, legal education and legal profession resources will be integrated, to carry out the teachers in the colleges and universities and professional institutions, sharing and information sharing [7].Will this goal by establishing a system of mutual teaching teachers and students exchange system, and so on.Secondly, the advancement of judicial professionalization, will be realize the benign interaction of law education and judicial professional opportunity.In the future of China in the process of rule of law, judicial professionalization is the trend of the times. 


\section{Summary}

Review of China's law education more than 60 years of development history, you can see that with legal professionals as the object of education legal professional education completed three transformation, that is, from make up a missed lesson type, temporary training to systematic and standardized training of change; Ranging from, knowledge training to the professional, the transition of the elite training; From the record of formal schooling education is given priority to the shift towards career continue to education is given priority to. Based on universal education object of the education carried out five times, has realized three leap, that is, from the education to all have the ability to accept the education of the citizen's enlightenment to improve the ability of leading cadres in accordance with the decision, in accordance with the management of national legal consciousness, with emphasis on the flight; By a single leap of universal laws to all-round law-based governance; The change from virtual to real, rule by law by the weak strong, leap to the institutionalization, standardization and legalization. Law education pattern has been formed in China.

\section{References}

[1] X.M. Xu, The responsibility of legal education, China university of political science and law press, 2010, vol.4, pp.32-36.

[2] X.D. Huo, Reflection of China's law education, China university of political science and law press, 2007, vol.6, pp. 69-73.

[3] L.L. Lin, 30 years of reform and opening-up and Chinese construction of law rule, Jurisprudence of China, 2008, vol. 4, pp.40-44.

[4] Q.H. Ye and X.Sh. Ding, The construction of law education and judicial examination of the benign interactive relationship - "seminar of law education and judicial examination" review , Jurisprudence of China, 2002, pp.2-6

[5] L.M. Zhang, A review of the judicial examination oriented discipline of law education, Legal system and social development, 2002, vol.6, pp.43-47.

[6] Ch.G. Wang, The necessary: "practicality law teaching and education reform of law", Beijing: higher education press, 2003, pp. 23-27.

[7] H.S. Wen, Contemporary legal education of jurisprudence perspective, The jurists, 2002, vol,2,32-36. 